\title{
Uczeń jako wartość. Porzucona misja polonistyki
}

\section{The lost mission of Polish Language Arts Education. Student as a maker}

\author{
|Witold Bobiński
Wydział Polonistyki Uniwersytet Jagielloński
}

\begin{abstract}
The article deals with the fundamental goal of the Polish Language Arts Education, regarded as the student's development within the area of humanity and key competences needed in contemporary world. The concept of education as the student's development has been known in Poland since the Twenties and the works of Kazimierz Wóycicki. The traces of his thoughts can be found nowadays in the modern educational ideas and concepts in Europe and the United States. This educational discourse concentrates on the ideas of dialogue, giving the students the great part of responsibility for their learning, differentiation and individualisation in teaching. Contemporary thoughts on education come from Jerome Bruner's ideas of self-effectiveness, self-esteem, self-evaluation and aspirations. These ideas, however, as well as the concept of student's development, are unfortunately very distant from the latest Polish reforms in education.
\end{abstract}

Key words: Polish Language Arts, teaching literature, learning, student's self-efficacy, student's development

Streszczenie: Tekst zawiera deklarację autora w kwestii fundamentalnego zadania edukacji polonistycznej, definiowanego jako rozwój ucznia w obszarze w wymiarze osobowości humanistycznej i w obszarze kompetencji kluczowych dla człowieka z pierwszych dekad XXI wieku. Koncepcja edukacji jako wspomagania rozwoju ucznia ma długą tradycję również w Polsce. Za jej patrona można uznać Kazimierza Wóycickiego, twórcę kategorii „przeżycia estetycznego" i zwolennika autentycznego i nieskrępowanego kontaktu młodych ludzi z tekstami literackimi. Intuicje edukacyjne Wóycickiego odbijają się w najnowszych koncepcjach i projektach europejskich i amerykańskich, które koncentrują się wokół koncepcji kształcenia jako spotkania, idei powierzania uczącym się odpowiedzialności za uczenie, nauczania zróżnicowanego i indywidualizowanego. We współczesnym myśleniu o edukacji masowej kluczowa jest, zgłoszona przez Jerome'a Brunera, idea kształtowania poczucia sprawstwa u uczniów, budującego samoocenę i oczekiwania wobec samego siebie. To jednak, co bliskie było Wóycickiemu i jego kontynuatorom, co stanowi dziś centrum dyskursu edukacyjnego, okazuje się nad wyraz dalekie od wektora najnowszych reform oświatowych w Polsce.

Słowa kluczowe: język polski, kształcenie literackie, uczenie się, poczucie własnej sprawczości ucznia, rozwój ucznia 
Nauczyciel ma przed soba nie tube fonografu, ale gromadke zainteresowanych ludzi.

Kazimierz Wóycicki

Zacznę od konkluzji: największą wartością dla szkoły jest uczeń, najważniejszą wartością dla edukacji jest osoba ucząca się. Jeśli edukacja i szkoła nie respektują tej hierarchii, to nie tylko nie czynią nic dobrego, ale czynią zło. To nie jest cytat z dzieła któregoś z klasyków edukacji, to moja deklaracja, to moje wyznanie niezachwianej wiary w kształt edukacyjnej hierarchii wartości. Formułuje je w słowach prostych i bezpośrednich, na takie słowa czas dziś jest najwyższy. Przedmiot określany jako język polski i szkolna polonistyka jako przedmiotowa sztuka nauczania również mają - $\mathrm{w}$ pierwszym rzędzie - służyć rozwojowi ucznia. To przekonanie jest równie oczywiste dla studentów polonistyki, jak i dla najważniejszego dziś badacza edukacji, Johna Hattiego, i najgłośniejszego edukacyjnego wizjonera, Kena Robinsona. Definiuje ono model kształcenia realizowany w wiodących systemach edukacyjnych świata, patronuje też wprowadzanej właśnie w Finlandii, fundamentalnej reformie programowej. To przekonanie, tyleż oczywiste, co u nas zapoznane, było również nieodłącznym atrybutem refleksji o nauczaniu formułowanej blisko sto lat temu przez patronów szkolnej polonistyki. Jeden z nich pisał o konieczności „wyrabiania samodzielności młodzieży”, „wzrostu intelektualnego", „wzmożenia energii działania”, „osobistej obserwacji”, „przyzwyczajania do samodzielnego, obmyślonego, planowego, dokładnego działania". Opowiadał się ów badacz i dydaktyk przeciwko niszczeniu „naturalnej skłonności młodzieży do czytania” i „rozkoszy samodzielnego zdobywania”. Często przywoływana w tych fragmentach „samodzielność" jest jednym z fundamentalnych celów edukacji polonistycznej, której wizję przedstawił w wydanej w 1921 roku rozprawie Rozbiór literacki w szkole Kazimierz Wóycicki. Zasady nowoczesnej szkoły upatrywał Wóycicki - wzorem ówczesnych pedagogów i badaczy edukacji - w „obserwacji osobistej ucznia" - a więc w doświadczeniu osoby uczącej się. Uczeń w centrum życia szkolnego, szkoła jest dla ucznia - ileż razy powtarzaliśmy te truizmy ostatnimi i dawniejszymi laty? Jaki zrobiliśmy z nich użytek, w jakim stopniu ukształtowaliśmy naszą pracę zgodnie z hasłami o stuletniej już historii? Pisał Wóycicki:

najdoskonalszą nauką literatury jest wspólne czytanie utworów z wymianą myśli i uczuć, gdzie każdy ma swobodę interpretacji, spowiedzi ze swych spostrzeżeń, nauczyciel zaś obowiązany jest do obserwowania reakcji uczniów, spotykanych trudności, niesienia pomocy, kierowania pracą i wyciągania stąd wniosków na przyszłość.

Im więcej rozumnych pytań będzie padało ze strony uczniów, im te pytania będą głębsze, im częściej uczniowie sami sobie odpowiedzą, im bardziej praca nauczyciela sprowadzi się tylko do kontrolowania biegu myśli młodych czytelników, utrzymywania porządku w toku wypowiadanych uwag i spostrzeżeń, tem lepiej wykonał 
on swoje zadanie, tem większy triumf poety. Lekcja straciła charakter narzuconej obowiązkowej pracy, stała się swobodnem obcowaniem ze sztuką, rozmową, mieniącą się różnobarwnie, tryskającą niespodziankami indywidualnych reakcyj, to snuciem jednej myśli, to starciem różnych zdań, żywem zespoleniem czytelników między sobą i czytelników z dziełem (Wóycicki 1921, 15).

Wspólnota czytających, swoboda reakcji, obserwacja i diagnoza, autorefleksja nauczyciela, wsparcie, modyfikowanie nauczania, zaangażowanie uczniów, rozmowa, otwartość na inność, wartość różnicy zdań, budowanie relacji - wszystkie te nośne dziś w dyskursie edukacyjnym i humanistycznym kategorie odnajdziemy w myśli dydaktycznej Wóycickiego. Warszawski polonista sprzed wieku zdradza intuicję kształcenia przekraczającego podziały na grupy wiekowe, mówiąc, iż wspólne czytanie literatury „unicestwia granice, dzielące klasy niższe i wyższe w zakresie nauki polskiego" (Wóycicki 1921, 15). Im dalej, tym bardziej zaskakująco - Wóycicki postuluje specjalną aranżację przestrzeni („wynalezienie cichej sali, gdzie (...) hałasy (...) nie rozpraszają uwagi", Wóycicki 1921, 18), wprowadzenie dobrego klimatu i stworzenie stosownego środowiska uczenia sie - nazywa to „przygotowaniem do lektury", przygotowaniem ducha i ciała. Nie ma dobrej lektury bez przyjaznej atmosfery dla ucznia i dzieła - uważa autor Rozbioru literackiego... Nie ma dobrej lektury przy braku „podniety”, lekceważeniu uczuć młodych ludzi, w sytuacji nudy i zniechęcenia - te zjawiska to główni wrogowie dobrego czytania i skutecznego nauczania.

Bądźmy precyzyjni - Kazimierz Wóycicki w dziele z końca drugiej dekady $\mathrm{XX}$ wieku w żadnym miejscu nie formułuje explicite tezy o rozwoju ucznia jako o podstawowym zadaniu edukacji i szkoły. Wielokrotnie jednak deklaruje solidarność z taką wizją nauczania (literatury), która - stawiając w centrum dzieło - projektuje jednocześnie swoiste okoliczności i warunki zdarzenia lektury, lektury uczniowskiej. W procesie nauczania literatury kluczowym zdarzeniem jest lektura ucznia i to właśnie jego dyspozycjom i oczekiwaniom podporządkowuje Wóycicki akt szkolnego czytania. „Nauczyciel ma przed sobą nie tubę fonografu, ale gromadkę zainteresowanych ludzi” (Wóycicki 1921 , 38) - powiada, upominając się o strategię czytania, która chroni jak najwięcej z naturalnego, swobodnego spotkania z tekstem. Antropocentryczny, a wręcz „uczniocentryczny” wymiar kształcenia literackiego podkreśla słowami „ciekawości człowieka w stosunku do człowieka należy dać folgę”, przesuwając na peryferie zdarzenia lektury aspekty ważne dla filologa, zwłaszcza zaś - historyka literatury. Wóycicki - wróg pośpiechu w czytaniu i wykładu jako metody - deklaruje, iż w procesie kształcenia polonistycznego „głównym celem jest pogłębione przeżywanie utworów” (Wóycicki 1921, 85), przeżywanie uczniowskie - rzecz jasna. Proponowana w realizacji tego celu strategia wspólnego czytania i omawiania tekstów literackich nie może pomijać (opisanego wszak jeszcze przez spadkobierców Herbarta) ogniwa zastosowania zdobytych umiejętności i wiedzy. 
W tej dziedzinie nauczyciel tak powinien kierować pracą, takie obmyślać uczniom zadania, aby zamiast mechanicznego powtarzania zdobytych wiadomości młodzież oglądała poznane fakty literackie, to jest dzieła z nowego stanowiska, dostrzegała w nich nieznane dotychczas zagadnienia, przyuczała się rozświetlać za pomocą zdobytych spostrzeżeń, myśli, uczuć problematy życia indywidualnego i zbiorowego, zdobywała wreszcie tę głęboką umiejętność harmonijnego splatania i spajania treści każdego dzieła z całym swoim dobytkiem wewnętrznym, z samym sposobem widzenia, odczuwania i myślenia o rzeczach (Wóycicki 1921, 94).

Wszak to właśnie definicja zjawiska, któremu na imię: czytelniczy, a w istocie duchowy czy wręcz humanistyczny rozwój człowieka - wdrażać się do poznawania tekstów kultury, budując tym samym swoiste repozytorium języka, a więc sposobów postrzegania, poznawania i mówienia o rzeczywistości. Jakież to współczesne - chciałoby się powiedzieć, przywołując w komentarzu tytuł książki Ryszarda Koziołka Dobrze się myśli literaturą ${ }^{1}$. Tylko strategia wspólnego czytania i omawiania literatury - utrzymuje Wóycicki - jest w stanie sprostać temu zadaniu, bo w niej „jest ruch, bije tętno zainteresowania, kipi życie” (Wóycicki 1921, 101). Zalety tej strategii (którą autor Rozbioru... postrzegał w kategoriach otwartej na emocje i różnorodność heurezy) to - między innymi - zjawiska uczenia się nauczyciela, budowania relacji i właśnie: rozwoju ucznia.

ileż nowych niespodzianych spostrzeżeń zbogaca umysł nauczyciela, ile nowych świateł pada na przedmiot, jaka radość, gdy się widzi wzrastające szybko przywiązanie młodzieży do przedmiotu, przechodzące wreszcie w miłość - gdy się widzi, jak uczniowie rozwijają się, jak się zbliżają ze sobą na tle wspólnych zainteresowań i przeżyć, gdy się wreszcie czuje coraz większe zacieśnienie węzłów między klasą i nauczycielem (Wóycicki 1921, 101-102).

Intuicje ujawniane $\mathrm{w}$ rozprawie Wóycickiego brzmią zaiste bardzo współcześnie i nietrudno znaleźć ich rozwinięcie i dowartościowanie w nowoczesnej myśli o edukacji.

\section{W sto lat po Rozbiorze...}

Jak daleko jesteśmy dziś od takich lekcji, od takiej szkoły i polonistyki szkolnej? Prawie równie daleko, jak od ustaleń i rekomendacji współczesnego dyskursu edukacyjnego, który koncentruje się na kategorii rozwoju ucznia lub - mówiąc słowami Johna Hattiego - na zjawisku tzw. widocznego uczenia się.

W ostatnich dwudziestu latach współczesna myśl o edukacji została poddana częściowej redefinicji, której ostatnią fazę mamy - jak się wydaje - za sobą. Za początek owej przemiany można uznać opublikowaną w połowie lat 90. XX wieku - klasyczną już dziś - Kulturę edukacji Jerome’a Brunera. W 1996 roku Bruner konstatował istnienie trzech zasadniczych antynomii definiujących refleksję nad edukacją i praktyczną realizację kształcenia systemowego. Antynomie te sprowadzały się do następujących pytań:

${ }^{1}$ Koziołek R., 2016, Dobrze się myśli literatura, Wołowiec. 
Czy edukacja powinna powielać kulturę, czy wzbogacać i udoskonalić ludzki potencjał? Czy powinna opierać się na zróżnicowanym doskonaleniu wrodzonych zdolności dzieci z najlepszym genetycznym uposażeniem, czy też stawiać na zaopatrywanie wszystkich dzieci w kulturowy zestaw narzędzi, który umożliwiłby im pełną efektywność? Czy powinniśmy dawać pierwszeństwo wartościom i zwyczajom kultury jako całości, czy przyznawać honorowe miejsce tożsamościom składających się na nią subkultur? (Bruner 2006, 117-118).

Konstatując brak możliwości udzielenia jednoznacznych i precyzyjnych odpowiedzi na powyższe pytania i oddalając zdroworozsądkową intuicję poszukiwania złotego środka pomiędzy członami antynomii, Bruner zgadzał się jednak z sugestią, że każdy z członów, w jakimś stopniu, zasługuje na aprobatę. Zamiast jednak pracowicie obmyślać sposoby pogodzenia sprzeczności, amerykański badacz zaproponował sposób przekroczenia („zignorowania”) tego problemu, decydując się na obserwację i wykorzystanie doświadczeń i dobrych praktyk tych szkół amerykańskich, w których dochodziło do budowania prawdziwych wspólnot uczących się i razem angażujących się w rozwiązywanie problemów. Świadomy nadciągającej rewolucji kulturowej i społecznej, Bruner wyrażał przeświadczenie o konieczności przemiany „szkoły jako kultury uczenia się”, ale także zmiany roli nauczyciela. Sformułowana przez amerykańskiego badacza wizja owej przemiany koncentrowała się wokół czterech kluczowych pojęć (idei): sprawstwa, refleksji, wspótpracy, kultury. Wizja nowej filozofii edukacyjnej Brunera, wsparta na czterech ideach kluczowych, skupia się zasadniczo na dwóch fenomenach procesu kształcenia: uczniu i uczeniu się. Zarówno bowiem sprawstwo i refleksja, jak i współpraca i kultura to kategorie spajające osobę ucznia i sam proces uczenia się. Sprawstwo to obszar kierowania tym procesem, refleksja to kwestia jego kształtowania, modyfikacji, współpraca to sfera organizacji uczenia się i jego okoliczności, kultura wreszcie - to mechanizmy włączania efektów uczenia się w strumień życia. W wizji Brunera, obok ucznia i uczenia się, dyskretnie pojawia się także i nauczyciel - uczeń zwiększa „stopień zarządzania własną aktywnością”, ale jej całkowicie nie przejmuje, współpracuje wszak z nauczycielem. Wektor tych przemian miał się jednak wyraźnie kierować ku uczniowi.

Współczesny dyskurs edukacyjny, formułowany głównie w krajach anglosaskich i skandynawskich, przyznaje dziś rację Brunerowi. Jego wizję potwierdzają wyniki badań edukacyjnych. Triada uczeń - uczenie się - nauczyciel pozostaje dziś w centrum nowoczesnej myśli oświatowej, zaś jej elementy postrzegane są w wielopiętrowym sprzężeniu zwrotnym. Idee te prosto i odważnie wyraża preambuła najnowszej podstawy programowej dla szkolnictwa podstawowego w Finlandii:

Celem edukacji na szczeblu podstawowym (7 do 16 roku życia - przyp. W. B.) jest wspieranie rozwoju uczniów w kierunku kształtowania ich człowieczeństwa 
i etycznie odpowiedzialnego uczestnictwa w społeczeństwie, a także wyposażenie uczniów w wiedzę i umiejętności potrzebne w życiu².

(Jakże cieszyłby się z tego „człowieczeństwa” Wóycicki). Przekonanie takie $\mathrm{w}$ innych słowach ujmuje jeden $\mathrm{z}$ najgłośniejszych dziś badaczy i znawców edukacji, John Hattie. Nowozelandczyk, profesor uniwersytetów w Auckland i w Melbourne, stwierdza, iż „szkoła jest przestrzenią, w której organizuje się warunki potrzebne do tego, aby zaistniało zjawisko uczenia się”. Niewątpliwie „wspieranie rozwoju uczniów” odbywa się przez stymulowanie ich „uczenia się”. Znaczenie tego pojęcia we współczesnej myśli edukacyjnej sprowadza się do rozumienia, rozumowania, pogłębiania rozumienia, a także: zdobywania umiejętności wykonywania czegoś. Sama transmisja wiedzy nie jest tożsama z uczeniem się. Owo fińskie przysposabianie do „człowieczeństwa” i „etycznie odpowiedzialnego uczestnictwa w społeczeństwie" można rozwinąć i doprecyzować cytatem z Widocznego uczenia się dla nauczycieli Hattiego, który do najważniejszych celów oświaty zalicza:

- rozwijanie umiejętności krytycznego myślenia;

- kształtowanie umiejętności analizy, refleksji i argumentacji;

- kształtowanie postawy troski o życie, zdrowie i dobro własne i innych;

- rozwijanie zdolności postrzegania świata z punktu widzenia innych;

- wdrażanie do akceptacji i doceniania różnicy zdań (Hattie 2013, 22).

W koncepcji Hattiego i podobnych mu badaczy edukacji, choćby Carol Ann Tomlinson, rozwój ucznia jest stymulowany przez opiekuńczego, spostrzegawczego, refleksyjnego, odpowiedzialnego, nieustannie badającego siłę swego oddziaływania nauczyciela. Ta lista epitetów jest konieczna, by właściwie zdefiniować rolę osoby uczącej w nowoczesnej wizji oświaty powszechnej. Powołaniem tej osoby, jej misją, zadaniem, jest systematyczne wspieranie uczniów w rozwoju. Taką filozofię edukacji ilustrują słowa jednej z amerykańskich nauczycielek, cytowane przez Tomlinson:

Codziennie będę was skłaniać do zrobienia kolejnego kroku do sukcesu. Nie dla każdego z was będzie to ten sam krok, ale mimo to okaże się on właśnie tym, czego w danej chwili będziecie potrzebować, by rozwinąć się jako ktoś, kto się uczy (Tomlinson 2011, 2).

Jeśli uczeń i jego rozwój są dla szkoły, dla edukacji, najwyższymi wartościami, to strategia wspierania rozwoju ucznia jest tego stanu rzeczy nieuchronną implikacją. Jest to strategia wymagająca i trudna - wymaga czasu, organizacji, mądrego planowania, uważności i konsekwencji, potrzebuje otwartości i życzliwości dla innych, dobrych relacji, kreatywności. Dla jej realizacji niezbędny jest luz programowy, specjalna aranżacja przestrzeni uczenia się oraz - last but not least - nauczyciel wspomagający.

${ }^{2}$ http://www.oph.fi/english/education_system/basic_education_Dostęp: 19.11.2017. 
Taka strategia nie ma szans zaistnieć w przeludnionej klasie pędzącej na wyprzódki przez dogęszczoną go granic możliwości czasoprzestrzeń roku szkolnego. Tę alternatywę trzeba przedstawić jasno: albo kult programu nauczania i jego bezwarunkowej realizacji - albo filozofia wspierania rozwoju umiejętności i kompetencji uczniów - przy zastosowaniu oceniania kształtującego, z wykorzystaniem indywidualizacji i różnicowania. Strategia ta wymaga nieodwołalnie realnej wolności nauczyciela w kreowaniu swojego nauczania, w różnicowaniu zawartości treści, kształtu procesu edukacyjnego, efektów pracy uczniów, środowiska/miejsca uczenia się. Strategia, o której mówimy, jest wyborem na miare współczesności, w której szkoła każdego dnia musi uzasadniać swoją niezbędność.

Jeśli Kazimierz Wóycicki, jakimś cudem, ogląda to, co na Ziemi dzieje się $\mathrm{z}$ edukacją $\mathrm{w}$ językach ojczystych, to zapewne sympatyzuje ze szkołą dla ucznia - z wizją refleksyjnego nauczyciela, rozwijających się uczniów, budowania więzi i relacji. On nie wyobrażał sobie szkoły bez kanonu (jak w większości europejskich państw), ale był przeciwnikiem rozepchanych programów! „Cała litanja nazwisk, wyuczona na pamięć, nie ma tej wartości dla umysłu, co dobre przestudjowanie jednego - jedynego autora" (Wóycicki 1921, 6-7). Ogromnie szkoda, że jego rozpoznania i intuicje, podobnie jak koncepcje jego następców i naśladowców (vide - Stanisław Bortnowski) konfrontują się dziś z oficjalnie zadekretowaną, archaiczną wizją kształcenia.

\section{Bibliografia}

Bruner Jerome, 2006, Kultura edukacji, Brzostowska-Tereszkiewicz T. (przeł.), Kraków.

Hattie John, 2013, Widoczne uczenie się dla nauczycieli. Jak maksymalizować siłe oddziaływania na uczenie się, Janowska Z. (przeł.), Pater M. (współpraca), Warszawa.

http://www.oph.fi/english/education system/basic education Dostęp: 19.11.2017.

Tomlinson Ann Carol, 2011, Differentiation and the Brain, How Neuroscience Supports the Learner-Friendly Classroom, Bloomington.

Wóycicki Kazimierz, 1921, Rozbiór literacki w szkole. Podręcznik dla nauczycieli, Warszawa.

\section{O Autorze:}

Witold Bobiński - dr hab., pracownik Katedry Polonistycznej Edukacji Nauczycielskiej na Wydziale Polonistyki UJ. Wieloletni nauczyciel języka polskiego, autor kilku serii podręczników języka polskiego dla wszystkich typów szkół (m.in. Świat w słowach i obrazach, Lustra świata) i historii dla gimnazjum i szkoły podstawowej. Ekspert MEN w pracach nad podstawą programową w latach 2008-2009. Wieloletni współpracownik Instytutu Badań Edukacyjnych, wykładowca w Szkole Edukacji Polsko-Amerykańskiej Fundacji Wolności i UW. Ostatnio opublikował rozprawę Wykształcić widza. Sztuka oglądania w edukacji polonistycznej (Kraków 2016). 
